\title{
Hubungan Antara Kontrol Diri Dengan Gaya Hidup Hedonisme Remaja Di Kafe Kota Padang
}

\author{
Elsa Irmeiyanti Hersika, Krisnova Nastasia Harri Kurniawan \\ Universitas Putra Indonesia "YPTK" Padang, Indonesia \\ email: elsahersika20@gmail.com krisnova88@gmail.com arikkurniawan17@gmail.com
}

\begin{abstract}
This study aims to determine the relationship between self-control and adolescent hedonism lifestyle in Padang City with a population of 98,884 adolescents and as many as 100 people while the data collection technique uses incidental sampling. Based on the hypothesis test conducted shows that there is a strong relationship between the relationship between self control and adolescent hedonism lifestyle in the city of Padang which is shown by the correlation coefficient rxy $=-0,824$ with a significant level of correlation $p=0,000$. A positive value on the correlation coefficient shows the relationship between self control and the adolescent hedonism lifestyle in Padang City, meaning that the higher the self-control of adolescents the lower the hedonism lifestyle and conversely the more self-control the lower the hedonism lifestyle. The amount of effective contribution $(R$ square) of the hedonism lifestyle variable to self control is $68 \%$, which means that hedonism lifestyle has a contribution of $68 \%$ to self control while $32 \%$ is influenced by other factors.
\end{abstract}

Keywords: Self Control, Hedonisme Lifestyle, Youth

\begin{abstract}
Abstrak
Penelitian ini bertujuan untuk mengetahui hubungan antara kontrol diri dengan gaya hidup hedonisme remaja di Kota Padang denhan populasi sebanyak 98.884 remaja dan samle sebanyak 100 orang adapun teknik pengambilan data menggunkan incidental sampling. Berdasarkan uji hipotesis yang dilakukan menunjukan bahwa terdapat hubungan yang kuat hubungan antara kontrol diri dengan gaya hidup hedonisme remaja di Kota Padang yang ditunjukan oleh angka koefisien korelasi $r_{x y}=-0,824$ dengan tingkat signifikan korelasi $p=0,000$. Nilai yang positif pada koefisien korelasi menunjukan hubungan antara kontrol diri dengan gaya hidup hedonisme remaja di Kota Padang, artinya bahwa semakin tinggi kontrol diri remaja maka semakin rendah gaya hidup hedonisme dan sebaliknya semakin kontrol diri maka semakin rendah gaya hidup hedonisme. Adapun besar sumbangan efektif ( $R$ square) dari variabel gaya hidup hedonisme terhadap kontrol diri adalah sebesar $68 \%$ artinya gaya hidup hedonisme memiliki sumbangan sebesar $68 \%$ terhadap kontrol diri sedangkan $32 \%$ dipengaruhi oleh faktor lain.
\end{abstract}

Kata Kunci: Kontrol Diri, Gaya Hidup Hedonisme, Remaja.

\section{Pendahuluan}

Masa remaja adalah periode dimana seseorang mulai bertanya-tanya mengenai berbagai fenomena yang terjadi di lingkungan sekitarnya sebagai dasar bagi pembentukan nilai diri mereka. Elliot Turiel (dalam Resita, 2016) ${ }^{[8]}$ menyatakan bahwa para remaja mulai membuat penilaian tersendiri dalam menghadapi masalah-masalah populer yang berkenaan dengan lingkungan mereka. Masa remaja berlangsung dari usia 12 tahun hingga usia 21 tahun, pada masa remaja ini dibagi menjadi 3 tahap yaitu usia 12-15 tahun adalah masa remaja awal, 15-18 tahun adalah masa remaja tengah dan usia 1812 tahun adalah masa remaja akhir, monks (dalam Fadhullhadi, 2012) ${ }^{[6]}$. Pada masa remaja ini dikenal sebagai masa transisi dari masa anak-anak menjadi dewasa, pada masa ini remaja banyak mengalami perubahan-perubahan pada sejumlah aspek dalam kehidupannya dalah satunya dalam gaya hidup.

Gaya hidup merupakan gambaran bagi setiap orang yang mengenakannya dan menggambarkan seberapa besar nilai moral orang tersebut dalam masyarakat di sekitarnya dan bagaimana cara orang 
tersebut hidup sebagian besar remaja zaman sekarang itu menyalah gunakan gaya hidup apalagi remaja-remaja yang tinggal dikota sebagian besar mereka lebih mengikuti trendmode dimasa kini seperti contohnya berpakaian seberti orang kebarat-baratan,ngemall dll, remaja zaman kini itu selalu di kaitkan dengan zaman dan teknologi Siklus kehidupan yang seperti ini seakan menjadi suatu pola baru dan gaya hidup baru salah satunya gaya hidup hedonisme

hedonisme berasal dari bahasa Yunani yaitu hedone yang berarti kesenangan. Hedonisme adalah pandangan hidup yang menganggap bahwa kesenangan dan kenikmatan hidup adalah tujuan utama, Menurut Wojowasito (dalam Ajeng K, 2010) ${ }^{[1]}$, Sedangkan Sujanto (dalam Ajeng K, 2010) ${ }^{[1]}$ menjelaskan bahwa gaya hidup hedonis yang berorientasi pada kesenangan umumnya banyak ditemukan di kalangan remaja. Hal ini karena remaja mulai mencari identitas diri melalui penggunaan simbol status seperti mobil, pakaian, dan pemilikan barang-barang lain yang mudah terlihat.

Menurut Well dan Tigert (dalam Anjelita, 2017) ${ }^{[2]}$, aspek-aspek gaya hidup hedonis yaitu minat, aktivitas dan opini. Minat diartikan sebagai apa yang menarik dari suatu lingkungan individu tersebut memperhatikannya. Minat dapat muncul terhadap suatu objek, peristiwa, atau topik yang menekan pada unsur kesenangan hidup yaitu fashion, makanan, benda-benda mewah, tempat berkumpul, dan selalu ingin menjadi pusat perhatian. Aktivitas yang dimaksud adalah cara individu menggunakan waktunya yang berwujud tindakan nyata yang dapat dilihat misalnya lebih banyak menghabiskan waktu di luar rumah, lebih banyak membeli barang-barang yang kurang diperlukan, pergi ke pusat pembelanjaan dan kafe. Opini adalah pendapat seseorang yang diberikan dalam merespon situasi ketika muncul pernyataan-pernyataan atau tentang isu-isu sosial dan produk-produk yang berkaitan dengan hidup.

Kecenderungan gaya hidup hedonisme tampak pada remaja di Indonesia khususnya di kota besar, mulai maraknya kafe-kafe, restoran,tempat nongrong di kota padang tampaknya memberikan pengaruh besar terhadap prilaku hedonisme pada saat ini, melalui survei yang dilakukan dinas pariwisata dan kebudayaan Kota Padang pada tahun 2014-2016 diketahui kafe-kafe yang ada di Kota Padang berkembang pesat,pada tahun 2014 jumlah kafe yang ada di Kota Padang sebanyak 20 kafe, Sedangkan pada tahun 2016 jumlah kafe yang ada di Kota Padang mencapai 160 kafe, begitu pula dengan restoran dan rumah makan. Pada wawancara yang dilakukan disalah satu restoran cepat saji dan juga merupakan tempat nongkrong yang digemari remaja,salah satu pelayan restoran menyatakan bahwa konsumen yang paling banyak adalah remaja, yang sering nongkrong pada saat jam pulang sekolah sampai malam apalagi hari libur atau weekend.

Menurut penuturan beberapa remaja yang pada saat itu sedang nongkrong mengatakan bahwa mereka biasa nongkrong di tempat biasanya 3-4 kali dalam seminggu ketika pulang sekolah, ketika mereka melakukan kegiatan tersebut mereka merasa bahwa duduk-duduk sambil bercerita di kafe merupakan hal yang mengasikkan. Kemudian pada wawancara yang dilakukan di salah satu kafe yang terletak di MP, salah satu perkumpulan remaja mengatakan bahwa ketika duduk di kafe mereka biasa melakukan beberapa aktivitas seperti mengobrol dan memperhatikan gaya berpakaian yang sedang trend, dan mereka biasanya duduk di kafe-kafe yang mereka anggap bagus untuk berfoto, dalam satu kali nongkrong biasanya mereka dapat menghabiskan uang sampai 150 ribu rupiah. Wawancara dan observasi yang dilakukan di kafe ketiga di daerah kuranji salah satu remaja mengatakan bahwa ketika nongkrong di kafe ia dapat berkumpul dan bermain game secara bersamaan di tempat yang nyaman seperti kafe yang mereka kunjungi bahkan ia dan teamn-temannya dapat mengungjungi kafe untuk bermain game online setiap malam, dari jam 19:00-23:00 dan mereka menghabiskan diatas 100 ribu rupiah dalam satu kali nongkrong, kemudian dengan nongkrong di kafe ia dapat memperbarui story di media sosial .

Wawancara dan observasi yang di lakukan di IK di salah satu pusat perbelanjaan beberapa remaja mengatakan bahwa tempat tersebut enak untuk mereka jadikan tempat nongkrong dan tempat tersebut juga memiliki gaya yang mewah. Kemudian wawancara selanjutnya dilakukan di kafe yang terletak di kawasan gelanggang olah raga, remaja yang di wawancarai mengatakan bahwa mereka duduk di 
kafe tersebut setiap hari sabtu dan minggu itu bertepatan dengan hari wajib bagi mereka untuk kumpul bersama anggota dari komunitas mobil yang mereka ikuti mereka melakukan kegiatan tersebut dari sore sampai jam 11 malam, dan dalam kegiatan tersebut mereka dapat menghabiskan uang kisaran 250 ribu rupiah.

Wawancara berikutnya dilakukan disalah satu restoran, pada wawancara ini subjek merupakan kumpulan dari anak-anak perempuan mereka mengatakan bahwa mereka dapat berpindah-pindah tongkrongan sesuai yang mereka inginkan dalam tiap minggu sebanyak 4-5 kali, dalam kegiatan yang mereka lakukan selain duduk-duduk nongkrong mereka juga melaukan arisan mingguan,dan bercerita seputar fashion, observasi terakhir dilakukan di restoran di tempat perbelanjaan, pada saat wawancara ini subjek yang ditemui masih menggunakan baju sekolah mereka, mereka mengatakan mereka melakukan kegiatan tersebut untuk menghiangkan penat sesuadah sekolah,biasanya mereka nongkrong di kafe 2 kali dalam setiap minggunya.

Perilaku gaya hidup yang tampak di kalangan remaja saat ini di samping adanya perubahan dari kehidupan masyarakat yang modern, diyakini pula adanya perubahan pada proses perkembangan di dalam diri remaja. Gunarsa (dalam Ajeng k, 2010) ${ }^{[1]}$ menyebutkan bahwa dalam proses perkembangannya individu dalam masa remaja mengalami suatu perkembangan yang semakin diarahkan keluar dirinya, keluar lingkungan keluarga dan akhirnya ke dalam masyarakat dan tempat yang akan ditempati di dalam masyarakat. Gaya hidup hedonis tentu ada penyebabnya. Ada banyak faktor ekstrinsik (faktor yang datang dari luar) yang memicu emosi mereka menjadi hamba hedonisme. Marjohan (dalam Ajeng k, 2010) ${ }^{[1]}$ menyebutkan bahwa orang tua dan kaum kerabat adalah penyebab utama generasi mereka menjadi hedonisme. Mereka lalai untuk mewarisi anak dengan norma dan gaya hidup timur yang punya spiritual. berperan lagi yaitu faktor karakteristik kepribadian dari remaja itu sendiri, salah satunya yaitu kontrol diri

Kontrol diri merupakan suatu mekanisme yang dimiliki oleh setiap individu untuk membantunya dalam mengarahkan perilakunya Chaplin (dalam suryani dkk, 2012) ${ }^{[13]}$ mengungkapkan bahwa kontrol diri adalah kemampun untuk menekan atau merintangi impuls-impuls dan tingkah laku impulsife Self control merupakan salah satu fungsi pusat yang berada dalam diri individu. Self control dapat dikembangkan dan digunakan individu untuk mencapai kesuksesan dalam proses kehidupan. Pengaruh self control terhadap timbulnya tingkah laku dianggap cukup besar, karena salah satu hasil proses pengontrolan diri seseorang adalah tingkah laku yang tampak Zulkarnain, (dalam Ardilasari, 2017) ${ }^{[3]}$.

Untuk memahami gaya hidup pada remaja tidak hanya ditentukan pada faktor usia, kelompok sosial, namun lebih pada latar sosial budaya dan kepribadian remaja tersebut. Misalnya remaja yang tinggal di kota-kota besar, lebih cenderung memiliki gaya hidup yang menonjol dan lebih jelas dibandingkan remaja yang tinggal di desa. Manakala gaya hidup merupakan sesuatu yang dianggap penting dan menjadi prestige yang mengutamakan faktor kesenangan akan mengarah pada kecenderungan yang bersifat hedonis. Gaya hidup hedonis yang berorientasi pada kesenangan umumnya banyak di temukan dikalangan remaja Siregar (dalam Ajeng k, 2010) ${ }^{[1]}$. Menurut Sujanto (dalam Ajeng k, 2010) ${ }^{[1]}$ hal ini karena remaja mulai mencari identitas diri melalui penggunaan simbol status seperti mobil, pakaian, dan pemilikan barang-barang lain yang mudah terlihat. Gaya hidup hedonis berkaitan erat dengan kontrol diri pada remaja.

Pada wawancara dan observasi yang dilakukan kebanyakan dari subjek menyatakan bahwa mereka merasa senang dapat membeli barang-barang yang bermerek, kemudian mereka bisa mendapatkan teman yang memiliki pengetahuan yang tinggi terhadap barang bermerek, tempat tongkorongan yang hits serta mereka dapat mejadi pusat perhatian diantara teman-teman yang lain, sehingga mereka menilai jika gaya hidup ini sangat menyenangkan, bahkan ada yang mengatakan jika mereka tidak punya uang untuk membeli barang yang bermerek atau hanya sekedar untuk duduk di kafe mereka berusaha untuk memeproleh uang agar dapat memenuhi gaya hidup tersebut dengan berbagai macam cara meminjam keteman, atau membohongi orang tua dengan alasan kebutuhan sekolah. 
Penelitian tentang hubungan antara kontrol diri dengan gaya hidup hedonisme pernah dilakukan oleh peneliti lainnya salah satunya adalah penelitian yang dilakukan oleh Siti Fatimah (2013) dari Universitas Muhammadiyah Surakarta yang berjudul "Hubungan Antara Kontrol Diri Dengan Kecenderungan Gaya Hidup Hedonis Pada Mahasiswi Di Surakarta". Perbedaan penelitian yang akan peneliti lakukan dengan penelitian sebelumnya terletak pada sampel penelitian, tempat penelitian serta tahun dilakukanya penelitian.

Beberapa uraian tersebut menunjukkan bahwa kontrol diri berperan mencegah terjadinya gaya hidup hedonis pada individu, karena dengan kemampuan mengontrol diri remaja dapat mengatur dan mengarahkan bentuk-bentuk perilakunya melalui pertimbangan kognitif sehingga dapat membawa ke arah perilaku yang positif. Namun kenyataan yang ada makin derasnya arus informasi dan teknologi yang diserap secara "apa adanya" tanpa memilah-milah mana yang pantas dan tidak pantas untuk dilakukan menyebabkan remaja melalakukan gaya hidup hedonisme yang seharusnya tidak mereka lakukan.

\subsection{Gaya Hidup Hedonisme}

Hedonisme merupakan sebuah penyakit yang ditimbulkan akibat adanya virus hedon, hedonis merupakan satu sebutan yang dialamatkan kepada orang yang terkena penyakit hedonisme tersebut. Hedonisme itu sendiri merupakan prilaku yang menuhankan kenikmatan dan kesenangan pribadi, kemewahan, dan kemapanan di atas segalanya Supelli (dalam Yanti,Jjannah \& Nurbaity, 2016) ${ }^{[12]}$. Gaya hidup hedonisme adalah pola hidup seseorang sebagai proses penggunaan uang dan waktu yang dimiliki yang dinyatakan dalam aktivitas, minat, dan pendapat (opini) yang bersangkutan Hal tersebut diwujudkan dalam hal tertentu seperti fashion, makanan, benda-benda mewah, tempat berkumpul dan selalu ingin menjadi pusat perhatian. Orang-orang yang menganut gaya hidup hedonis lebih sering manghabiskan waktu diluar rumah seperti mal dan kafe Wells dan Tigert (dalam Saputri \& rachmatan, 2016) ${ }^{[9]}$.

\subsection{Aspek-aspek Gaya Hidup Hedonisme}

Menurut Wells dan Tigert (dalam Maisyaroh, 2016) ${ }^{[7]}$ aspek-aspek gaya hidup hedonis adalah: (1) Minat diartikan sebagai apa yang menarik dari suatu lingkungan individu tersebut memperhatikannya. Minat dapat muncul terhadap suatu objek, peristiwa, atau topik yang menekankan pada unsur kesenangan hidup. Antara lain adalah fashion, makanan, benda-benda mewah, tempat berkumpul, dan selalu ingin menjadi pusat perhatian. (2) Aktvitas yang dimaksud adalah cara individu menggunakan waktunya yang berwujud tindakan nyata yang dapat dilihat. Misalnya lebih banyak menghabiskan waktu diluar rumah, lebih banyak membeli barang-barang yang kurang diperlukan, pergi ke pusat perbelanjaan dan kafe. (3) Opini adalah pendapat seseorang yang diberikan dalam merespon situasi ketika muncul pertanyaan-pertnyaan atau tentang isu-isu sosial dan produk-produk yang berkaitan dengan hidup.

\subsection{Kontrol Diri}

Self-control merupakan kemampuan untuk menahan keinginan dan dorongan dalam diri sendiri. Selfcontrol mengacu pada kapasitas untuk mengubah tanggapan sendiri, terutama untuk mengarahkan seseorang sesuai dengan standar seperti cita-cita, nilai-nilai, moral, dan harapan sosial, dan untuk mendukung mereka dalam mengejar tujuan jangka panjang Baumeister (dalam Wahdah, 2016) ${ }^{[14]}$. Vohs \& Tice (dalam Wahdah, 2016) ${ }^{[14]}$, self-control dapat memungkinkan seseorang untuk menahan suatu response atau lebih, dengan demikian mereka bisa memunculkan response yang berbeda. Selfcontrol memegang peranan penting dalam memahami sifat dasar dan fungsi dari self-control. Menurut Averill (dalam Risma, 2012) ${ }^{[8]}$ Kontrol diri merupakan variabel psikologis yang mencangkup kemampuan individu dalam menelola informasi yang diinginkan dan yang tidak dinginkan, kamampuan inividu untuk memilih salah satu tindakan berdasarkan sesuatu yang diyakini. 


\subsection{Aspek Kontrol Diri}

Menurut Averill (dalam Risma, 2012) ${ }^{[8]}$ aspek-aspek yang terdapat dalam kontrol diri antara lain: (1) Kemampuan mengontrol perilaku situasi ialah kemampuan untuk memodifikasi suatu keadaan yang tidak menyenangkan, kemampuan ini terdiri dari kemampuan untuk mengontrol prilaku yaitu kemampuan menentukan siapa yang mengendalikan.(2)Kemampuan kontrol kognitif ialah kemampuan individu untuk mengolah informasi yang tidak diinginkan dengan cara menginterpretasikan menilai untuk memadukan suatu kejadian dalam suatu kerangka kognitif sebagai adaptasi psikologis atau mengurasi tekakanan.(3)Kemampuan mengontrol keputusan emampuan untuk memilih suatu tindakan berdasarkan suatu yang di yakini atau di setujui

\section{Metode Penelitian}

Jenis penelitian ini adalah kuantitatif korelasional dengan variabel penelitian Menurut Sugiyono $(2017)^{[10]}$ variabel penelitian Kontrol Diri (Y) dan Variabel Independen, (X) Gaya Hidup Hedonisme. Populasi pada penelitian ini adalah pengunjung kafe di Kota Padang sebanyak lebih dari 10.000 dengan sampel sebanyak 100 orang. Teknik pengambilan sampel dalam penelitian ini adalah incidental sampling yaitu teknik penentuan sampel berdasarkan kebetulan, yaitu siapa saja yang secara kebetulan bertemu dengan peneliti dapat digunakan sebagai sampel, bila dipandang orang yang kebetulan ini cocol sebagai sumber data.

Alat ukur yang digunakan dalam penelitian ini adalah skala gaya hidup hedonisme dan Kontrol diri. Menurut Azwar (2017) ${ }^{[4]}$ skala merupakan perangkat pertanyaan yang disusun untuk mengungkap atribut tertentu melalui respon terhadap pertanyaan tersebut. Skala dalam penelitian ini memiliki format respon dengan empat alternatif jawaban. Skala yang digunakan dalam penelitian ini menggunakan format respon jawaban model Likert, yaitu suatu metode pernyataan sikap yang menggunakan respon subjek sebagai penentu nilai skalanya yang telah dimodifikasi menjadi empat alternatif jawaban dan aitem-aitem dalam skala ini dikelompokkan dalam aitem favorable dan unfavorable. Bentuk skala yang digunakan untuk mengukur intensi prososial dan skala kepuasan pengguna menggunakan empat alternatif jawaban, yaitu SS (Sangat Setuju), S (Setuju), TS (Tidak Setuju), dan STS (Sangat Tidak Setuju).

Skala penelitian akan melewati berbagai tahap analisis yaitu uji normalitas digunakan untuk mengetahui apakah populasi data terdistribusi normal atau tidak. Uji normalitas menggunakan uji kolmogorov-Smirnov. Uji linearitas bertujuan untuk mengetahui apakah dua variabel mempunyai hubungan yang linear atau tidak. Dua variabel dikatakan mempunyai hubungan yang linear bila signifikasi (linearty) kurang dari 0,05.

Selain itu dilakukan uji Validitas, sejauh mana ketepatan dan kecermatan suatu alat ukur dalam melakukan fungsi ukurnya (Azwar, 2017) ${ }^{[4]}$. Suatu item dapat dianggap memiliki daya diskriminasi yang memuaskan jika berkorelasi signifikan terhadap skor total atau jika melakukan penilaian langsung terhadap koefisien korelasi bisa digunakan batas nilai berkriteria rxy $\geq 0,3$ (Priyatno, 2017) ${ }^{[14]}$. Data skala dikatakan memiliki daya beda tinggi jika koefisien korelasi lebih besar atau sama dengan 0,3 (rxy $\geq 0,3$ ) dan sebaliknya aitem skala dikatakan gugur jika koefisien korelasi lebih kecil dari $0,3(\mathrm{rxy} \geq 0,3)$.

\section{Hasil dan Pembahasan}

Peneliti menyebarkan 100 skala kontrol diri dan skala gaya hidup hedonisme dan meminta kesediaan kepada pengunjung tersebut untuk mengisi skala kemudian menjelaskan cara pengisian skala dengan 
cara memberikan skala secara langsung kepada pengunjung beberapa kafe di Kota Padang, Sebelum pengisian skala dilakukan, peneliti terlebih dahulu memberitahukan petunjuk pengisian dengan singkat dan jelas.

\subsection{Hasil}

Koefisien Validitas skala gaya hidup hedonisme dengan nilai corrected item-total correlation berkisar antara 0,350 sampai dengan 0,889 , dengan reabilitas 0,950 , validitas skala kontrol diri dengan nilai corrected item-total correlation berkisar antara 0,361 sampai dengan 0,886, dengan reabilitas 0,945.

Uji normalitas dalam penelitian ini menggunakan uji Kolmogorov-Smirnov. Priyatno (2017) ${ }^{[14]}$ menyatakan bahwa data yang dinyatakan berdistribusi normal jika signifikansi (p) lebih besar dari 0,05. Berdasarkan hasil pengolahan data dengan menggunakan program IBM SPSS 21.0, maka diperoleh hasil sebagai berikut :

Tabel 1. Uji Normalitas Skala Gaya Hidup Hedonisme dengan kontrol diri

\begin{tabular}{ccccc}
\hline Variabel & $\mathrm{N}$ & $\mathrm{KSZ}$ & $\mathrm{P}$ & Sebaran \\
\hline Gaya Hidup Hedonisme & 100 & 0,977 & 0,295 & Normal \\
Kontrol Diri & 100 & 0,735 & 0,653 & Normal \\
\hline
\end{tabular}

Nilai signifikansi pada skala gaya hidup hedonisme sebesar $\mathrm{p}=0,295$ dengan $\mathrm{KSZ}=0,977$ hasil tersebut menunjukan bahwa nilai $\mathrm{p}>0,05$, artinya sebaran gaya hidup hedonisme terdistribusi secara normal, sedangkan untuk skala Kontrol diri diperoleh nilai signifikansi sebesar $\mathrm{p}=0,653$ dengan KSZ $=0,735$ hasil tersebut menunjukan bahwa nilai $p>0,05$, artinya sebaran terdistribusi secara normal. Selanjutnya uji linearitas dapat dilihat pada tabel 2 berikut:

Tabel 2. Uji Linieritas Gaya Hidup Hedonisme dengan kontrol diri

\begin{tabular}{ccccc}
\hline $\mathrm{N}$ & $\mathrm{Df}$ & Mean Square & $\mathrm{F}$ & Sig \\
\hline 100 & 1 & 2280.410 & 195.840 & 0,000 \\
\hline
\end{tabular}

Berdasarkan tabel diatas, diperoleh nilai $\mathrm{F}=2280.410$ dengan signifikansi sebesar $\mathrm{p}=0,000$ dengan ketentuan $(\mathrm{p}<0,05)$, artinya varians pada skala gaya hidup hedonisme daan Kontrol diri tergolong linier.

Tabel 3. Hasil Uji Korelasi Antara Gaya Hidup Hedonisme dengan kontrol diri

\begin{tabular}{ccccc}
\hline $\mathbf{P}$ & $(\boldsymbol{\alpha})$ & $\begin{array}{c}\text { Nilai Korelasi } \\
(\mathbf{r})\end{array}$ & R square & Kesimpulan \\
\hline 0,000 & 0.01 & $-0,824$ & 0,675 & hipotesis diterima. \\
\hline
\end{tabular}

Berdasarkan tabel di atas, maka diperoleh koefisien korelasi antara variabel gaya hidup hedonisme dengan Kontrol diri yaitu sebesar $r=0,790$ dengan taraf signifikansi $p=0,000$. Hal ini menunjukkan adanya korelasi yang sangat kuat dan berarah negatif kedua variabel tersebut, yang artinya jika semakin tinggi gaya hidup hedonisme, maka semakin rendah Kontrol diri, sebaliknya jika semakin rendah gaya hidup hedonisme, maka semakin tinggi kontrol diri. Hal ini diperkuat dengan hasil uji signifikansi dengan bantuan IBM SPSS versi 21.0, didapatkan $\mathrm{p}=0,000<0,01$ level of significant $(\alpha)$, artinya hipotesis diterima, bahwa terdapat hubungan antaragaya hidup hedonisme dengan Kontrol diri remaja di kafe kota Padang 
Tabel 4. Descriptive Statistic

\begin{tabular}{lccccc}
\hline \multicolumn{1}{c}{ Variabel } & $\mathrm{N}$ & Mean & Std. Deviation & Minimum & Maximum \\
\hline Gaya Hidup Hedonisme & 100 & 69.4900 & 5.82488 & 59 & 100 \\
\hline Kontrol diri & 105 & 78.7500 & 7.46355 & 76 & 112 \\
\hline
\end{tabular}

Berdasarkan nilai mean empirik, maka dapat dilakukan pengelompokkan yang mengacu pada kriteria pengkategorisasian dengan tujuan menempatkan individu kedalam kelompok-kelompok yang terpisah secara berjenjang menurut suatu kontinum berdasarkan atribut yang diukur (Azwar, 2017) ${ }^{[4]}$ berdasarkan norma kategorisasi, diperoleh kategorisasi subjek penelitian pada variabel, gaya hidup hedonisme dan Kontrol diri sebagai berikut :

Tabel 5. Kategori Gaya Hidup Hedonisme Dan Kontrol Diri

\begin{tabular}{ccccc}
\hline Variabel & Skor & Jumlah & Persentase (\%) & Kategori \\
\hline Gaya Hidup \\
hedonisme & $<75$ & 12 & $11,4 \%$ & Rendah \\
\cline { 2 - 5 } & $75-89$ & 76 & $72,4 \%$ & Sedang \\
\cline { 2 - 5 } & $\geq 90$ & 17 & $16,2 \%$ & Tinggi \\
\hline \multirow{2}{*}{$\begin{array}{c}\text { Kepuasan } \\
\text { Pengguna }\end{array}$} & $<83$ & 11 & $10,4 \%$ & Rendah \\
\cline { 2 - 5 } & $83-99$ & 77 & $73,3 \%$ & Sedang \\
\cline { 2 - 5 } & $\geq 100$ & 17 & $16,2 \%$ & Tinggi \\
\hline
\end{tabular}

Berdasarkan tabel di atas, maka dapat diperoleh gambaran bahwa sebesar 11,4\% atau 12 orang dikategorikan memiliki gaya hidup hedonisme yang rendah, sebesar $72,4 \%$ atau 70 orang remaja dikategorikan memiliki gaya hidup hedonisme yang sedang, sebesar $16,2 \%$ atau 18 orang remaja dikategorikan memiliki gaya hidup hedonisme yang tinggi sedangkan untuk variabel kontrol diri diperoleh gambaran bahwa sebesar $10,5 \%$ atau 11 pengunjung memiliki kontrol diri yang rendah, sebesar 73,3\% atau 71 pengunjung memiliki kontrol diri yang sedang dan sebesar 16,2\% atau 18 pengunjung memiliki kontrol diri yang tinggi.

Besar sumbangan variabel prososial terhadap variabel kepuasan pengguna dapat ditentukan dengan menggunakan rumus koefisien determinan. Koefisien determinan adalah kuadrat dari koefisien korelasi yang dikali dengan $100 \%$. Adapun besar sumbangan efektif ( $R$ square) dari variabel prososial terhadap kepuasan pengguna adalah sebesar $68 \%$ artinya gaya hidup hedonisme memiliki sumbangan sebesar $62,4 \%$ terhadap kontrol diri sedangkan 32\% dipengaruhi oleh faktor lain faktor-faktor lain yang memberikan sumbangan efektif terhadap kecenderungan gaya hidup hedonis seperti faktor internal dan faktor eksternal. Faktor internal yaitu sikap dan keyakinan, pengalaman, pengamatan, konsep diri, motif dan persepsi, sedangkan faktor eksternal dipengaruhi oleh kelompok referensi, keluarga, kelas sosial, kebudayaan

\subsection{Pembahasan}

Penelitian ini bertujuan untuk mengetahui hubungan antara gaya hidup hedonisme dengan kontrol diri remaja di kafe Kota Padang. Berdasarkan uji hipotesis yang dilakukan menunjukan bahwa terdapat hubungan yang sangatkuat antara gaya hidup hedonisme dengan kontrol diri yang ditunjukan oleh angka koefisien korelasi $\mathrm{r}_{\mathrm{xy}}=-0,824$ dengan tingkat signifikan korelasi $\mathrm{p}=0,000$. korelasi Menunjukan hubungan antara gaya hidup hedonisme dengan kontrol diri remaja di kafe Kota Padang artinya jika semakin tinggi gaya hidup hedonisme, maka semakin rendah Kontrol diri, sebaliknya jika 
semakin rendah gaya hidup hedonisme, maka semakin tinggi kontrol diri Hal ini menyatakan bahwa hipotesis diterima.

Gaya hidup dan kepribadian merupakan dua hal yang sangat berkaitan. Setiap individu memiliki karakteristik, keunikan dan perbedaan perilaku yang ditentukan dari cara individu itu berperilaku. Mischel, Shoda dan Mendoza-Denton (dalam Fatimah, 2013) ${ }^{[6]}$ menyatakan bahwa proses terjadinya perilaku, jika ditinjau dari teori sosial kognitif menjelaskan bahwa adanya kemampuan individu dalam mengatur dan mengontrol perilaku dirinya meskipun kondisi lingkungannya berubah-ubah. Hal tersebut terjadi karena pikiran dapat mengarahkan seseorang untuk mengontrol perilakunya. Seseorang yang memiliki kepribadian yang rendah akan memiliki kecenderungan gaya hidup yang tinggi. Dalam kaitannya dengan kecenderungan gaya hidup hedonis pada remaja di Kota Padang, kontrol diri terbentuk dari perilaku yang ditunjukkan oleh remaja dalam kehidupannya.

Remaja yang memiliki kontrol diri yang tinggi cenderung mengarahkan perilakunya kearah yang positif. Selain itu cara berfikir remaja yang memiliki kontrol diri yang tinggi akan berfokus pada halhal yang membawa manfaat untuk diri dan orang disekelilingnya. Dalam mengambil sebuah keputusan remaja akan mempertimbangkan segala sesuatunya dengan matang. Remaja juga akan cenderung mengikuti segala informasi, sehingga remaja tersebut dapat memprediksi dan menyiapkan apa yang akan terjadi, hal ini dilakukan untuk mengurangi rasa takut dalam menghadapi sesuatu yang tidak diketahui. remaja yang sudah memiliki pengalaman masa lalu, tentang segala hal yang menyangkut gaya hidup dari lingkungan sekitarnya cenderung lebih mampu mengontrol dirinya

\section{Kesimpulan}

Berdasarkan hasil pengumpulan data dan analisis data yang telah dilakukan oleh peneliti, maka dapat ditarik kesimpulan yang sekaligus merupakan jawaban dari tujuan penelitian adalah sebagai berikut : (1) Terdapat hubungan yang signifikan antara gaya hidup hedonisme dengan kontrol diri remaja di Kota Padang Hubungan antara kedua variabel tersebut negatif yang artinya semakin tinggi kontrol diri remaja maka semakin rendah gaya hidup hedonisme dan sebaliknya semakin kontrol diri maka semakin rendah gaya hidup hedonisme. Hal ini berarti hipotesis diterima.(2) Adapun besar sumbangan efektif dari variabel kontrol diri dengan gaya hidup hedonisme adalah 68\%.

\section{Daftar Rujukan}

[1] Ajeng K, Rohma. 2010.Hubungan Kontrol Diri Dengan Gaya Hidup Hedonimse . Skiripsi Publikasi. Surakarta. Universitas Muhammadiyah Surakarta

[2] Anjelita, Ajeng. 2017. Hubungan Antara Regulasi Emosi Dengan Gaya Hidup Hedonisme Pada Komunitas X Di Semarang. Skripsi Publikasi. Salatiga. Universitas Kristen Satya Wacana

[3] Ardilasari, Noratika. 2017. Hubungan Self Kontrol Dengan Rilaku Cyberloafing Pada Pegawai Negeri Sipil. Jurnal Psikologi, Vol. 05, No.01. Universita Muhammadiyah Malang

[4] Azwar, Saifuddin. 2014. Penyusunan Skala Psikologi. Yogyakarta: Pustaka Pelajar.

[5] Bernatta, Ratu. 2017. Pengaruh Gaya Hidup Hedonisme Di Kalangan Remaja. Skiripsi Publikasi. Universitas Negeri Lmpung

[6] Nutvitria, Agnes. 2015. Pengaruh Gaya Hidup Hedonisme Terhadap Prilaku Pembelian Impulsive Pada Mahasiswa Jurusan PPB FIP UNY. Skipsi Publikasi. Universitas Negeri Yogyakarta

[7] Rachdianti, yuniar. 2011. Hubungan Antara Self Contol Dengan Intensitas Penggunaan Internet Remaja Akhir. Sirpsi Publikasi. Universita Islam Negeri Syarif Hidayatullah Jakarta

[8] Resita, Risme. 2016. Prilaku Hedonisme Remaja Di Mall Panakukkang Makasar, Skripsi Publikasi. Universitas Negeri Alauddin Makasar.

[9] Saputri, Racmatan. 2016. Religiusitas Dengan Gaya Hidup Hedonisme Sebuah Gambaran Pada Mahasiswa Universita Syiah Kuala, Jurnal Psikologi. Universitas Syiah Kuala.

[10] Sugiyono. 2017. Metode Penelitian Kuantitatif Kualitatif dan R\&D, Bandung: Alfabeta

[11] Suryabrata, Sumadi. 2014. Metodologi Penelitian Cetakan Ke 25. Jakarta: PT. Rajagrafindo Persada. 
Elsa Irmeiyanti Hersika, Krisnova Nastasia Harri Kurniawan

PSYCHE 165 Journal Vol 13 No 1 (2020 ) 1 - 9

[12] Yanti, Janah, Nurbaity. 2016. Dinamika Kecenderungan Gaya Hidup Hedonisme Dan Prilaku Seks Bebas Pada Remaja Putri. Jurnal Psikologi. Universitas Syiah Kuala.

[13] Trimartati, Novita. 2014. Studi Kasus Tentang Gaya Hidup Hedonisme Mahasiswa Bimbingan Dan Konseling. Jurnal Psikologi, Vol. 3 No.1. Universitas Ahmad Dahlan.

[14] Priyatno Dwi. 2017. Mandiri Belajar SPSS (Software PROGRAM Service Solution).

[15] Wulandari, Nurul. 2018. Identifikasi Kontrol Diri Dan Asertiitas Diri Anggota Geng Sekolah, Jurnal Psikologi, Vol. 4, No.3. Universitas Negeri Yogyakarta. 